\title{
Pengembangan Literasi Sekolah melalui Pelatihan Menulis Cerita
}

\author{
Yusniarsi Primasari ${ }^{1}$, Hesty Puspita Sari², Adin Fauzi ${ }^{*}$ \\ 1,2,3Universitas Islam Balitar, Blitar, Indonesia \\ *Corresponding Author: adinfauzi26935@gmail.com
}

\begin{abstract}
Info Artikel
Diterima : 30/09/2021

Direvisi: $15 / 10 / 2021$

Disetujui: 22/10/2021

Abstract. Referring to the result of Indonesia National Assessment Programme in 2017, the literacy (reading and writing skills) of elementary school students were still low, that is, only $46.83 \%$. This condition needs to be improved, and one of the ways to enhance it is by implementing Gerakan Literasi Sekolah (GLS)/School Literacy Movement. This community service aims to improve the students' writing skill as en effort to implement the GLS. This community service was conducted in the form of training of story writing. The training was implemented at one of the Islamic Elementary School in Blitar, East Java. The participants of the training included the students of grade 4, 5, and 6, totalling 52 students. The training was conducted by applying flipped classroom. The material is given to the students in the form of video that they should learn online, and subsequently they were given face-to-face writing guidance in the classroom. The results showed that the students were able to create a story about their experiences during the pandemic. The analysis of students' writing revealed that the students' abilities in composing a text was good. These abilities include developing ideas and using proper words and sentence structure. However, most of the students still encountered difficulties in using mechanics of writing, such as capitalization and punctuation. This needs to be followed up by intensifying writing activity at school, and generating other trainings to enhance the students' writing skill.
\end{abstract}

Keywords: literacy, training, writing, story

\begin{abstract}
Abstrak. Mengacu pada hasil Asesmen Kompetensi Siswa Indonesia (AKSI) pada tahun 2017, kemampuan literasi (membaca dan menulis) siswa sekolah dasar masih cukup rendah, yakni hanya 46.83\%. Kondisi ini membutuhkan ditingkatkan, dan salah satu solusinya dengan melaksanakan penerapan Gerakan Literasi Sekolah (GLS). Dengan pelaksanaan pengabdian masyarakat ini bermaksud untuk peningkatan kemampuan menulis siswa sekolah dasar/sederajat sebagai upaya untuk menyukseskan GLS. Kegiatan pengabdian ini dikemas dalam bentuk pelatihan menulis cerita. Pelatihan ini dilaksanakan di salah satu Madrasah Ibtidaiyah di Kabupaten Blitar, Provinsi Jawa Timur. Peserta pelatihan ini meliputi siswa/siswi yang belajar di kelas 4, 5, dan 6, dengan jumlah keseluruhan 52 siswa. Pelatihan ini dilaksanakan dengan menerapkan metode flipped classroom. Siswa diberikan materi dalam bentuk video untuk dipelajari secara daring, lalu diberikan bimbingan menulis secara tatap muka di dalam kelas. Hasil dari pelatihan ini menunjukkan bahwa siswa mampu menulis cerita tentang pengalaman pada masa pandemi. Hasil analisis cerita juga menunjukkan bahwa kemampuan mereka dalam menghasilkan tulisan juga cukup baik, antara lain kemampuan mengembangkan ide serta menggunakan kosakata dan tata bahasa. Namun, sebagian besar siswa masih terkendala dalam menerapkan teknik penulisan yang baik seperti huruf kapital dan tanda baca. Hal ini perlu ditindaklanjuti dengan lebih mengintensifkan kegiatan menulis di sekolah, serta mengadakan pelatihan-pelatihan agar kemampuan menulis siswa semakin meningkat.
\end{abstract}

Kata Kunci: literasi, pelatihan, menulis, cerita

How to Cite: Primasari, Y., Sari, H. P., \& Fauzi, A. (2020). Pengembangan Literasi Sekolah melalui Pelatihan Menulis Cerita. Prima Abdika: Jurnal Pengabdian Masyarakat, 1(4), 158-166. https://doi.org/10.37478/abdika.v1i4.1259

Copyright (c) 2021 Yusniarsi Primasari, Hesty Puspita Sari, Adin Fauzi. This work is licensed undera Creative Commons Attribution-ShareAlike 4.0 International License.

\section{Pendahuluan}

Kemampuan membaca dan menulis (literasi) merupakan suatu kemampuan yang sangat penting untuk dikuasai peserta didik dalam proses pendidikan dan pembelajaran. Kemampuan ini menjadi sebuah prasyarat untuk mempelajari ilmu-ilmu pengetahuan. Berdasarkan Undang-Undang tentang Sistem Pendidikan Nasional ("Undang-Undang Republik Indonesia Nomor 20 Tahun 2003 Tentang Sistem Pendidikan Nasional," 2003), khususnya pada bagian Prinsip Penyelengaraan Pendidikan Bab III Pasal 4 Ayat 5, disebutkan bahwa "Dengan mengembangkan budaya membaca, menulis, berhitung bagi seluruh masyarakat berarti telah diselenggarakannya 
pendidikan" Sayangnya, kondisi dimana masyarakat Indonesia memiliki dasar kemampuan dalam membaca dan menulis yang baik belum sepenuhnya tercapai. Mengutip dari Buku Panduan Literasi Nasional tahun 2017, skor Asesmen Kompetensi Siswa Indonesia (AKSI)/Indonesia National Assessment Programme (INAP) yang dalam hal ini mengukur kemampuan membaca, sains dan matematika bagi peserta didik sekolah dasar memperlihatkan hasil yang memprihatinkan Khusus pada kemampuan membaca siswa secara nasional, persentase kemampuannya hanya sebesar $46.83 \%$. Menurut survei kemapuan literasi, Indonesia harus bergerak serius dalam mengentaskan literasi bangsa atau anak anak akan jauh tertinggal secara pendidikan.

Untuk mengatasi persoalan ini, dibutuhkan suatu gebrakan/kegiatan yang baru dalam menanam rasa cinta dan menumbuhkan budaya untuk membaca dan menulis khususnya di lingkungan pendidikan. Tahun 2015 merupakan tahuan dikeluarkannya Permendikbud no. 21 oleh Kementerian Pendidikan dan Kebudayaan Indonesia yang berisi tentang penumbuhan budi pekerti yang di dalamnya mencakup Gerakan Literasi Sekolah (GLS) dengan mewajibkan peserta didik membaca buku nonpelajaran selama 10-15 menit sebelum pembelajaran dimulai. Gerakan Literasi Sekolah (GLS) bertujuan untuk menumbuhkan budaya membaca dan menulis pada warga sekolah, baik kepala sekolah, peserta didik, dan guru yang berujung pada kemampuan memahami informasi secara analitis, kritis, dan reflektif (Sari \& Setiawan, 2021). Faktanya, implementasi Gerakan Literasi Sekolah (GLS) tidaklah mudah. Tidak semua siswa bisa mengakses kegiatan literasi yaitu membaca dan menulis secara baik dan benar, serta berkelanjutan karena setiap sekolah tidak memilki kemampuan yang sama dalam mengakomodasi penciptaan lingkungan sekolah yang literat.

Meskipun menemui sejumlah tantangan, Gerakan Literasi Sekolah (GLS) tentu tetap harus ditindaklanjuti, mengingat berbagai manfaat yang bisa diperoleh siswa, khususnya dari kegiatan menulis. Kemampuan ini tidak bisa berdiri endiri harus memerlukan dukungan yang kuat oleh kemampuan seperti membaca (reading), menyimak (listening) yang baik (Herry Setyawan et al., 2019). Berdasarkan pendapat para ahli, dengan menulis seseorang dapat mengenali kemampuan dan potensi dirinya, menggagas berbagai ide, berpandangan dan berwawasan luas, memberikan solusi solusi permasalahan, meninggalkan gagasan secara lebih objektif, menempatkan diri sebagai seoraang penemu sekaligus pemecah masalah, dan melakukan kebiasaan berpikir serta tertib dalam berbahasa (Guntur, 2008; Dalman, 2014).

Selain itu, melalui kegiatan menulis siswa bisa dibiasakan untuk menghargai proses. Hal ini dikarenakan kegiatan menulis sendiri bukan semata-mata soal hasil, namun ada beberapa langkah yang perlu diperhatikan untuk menghasilkan katya/tulisan yang baik. Menurut Dalman (2014), ada tiga tahap yang dilalui penulis. Pertama, tahap pra-penulisan. Tahapan pertama yang dilakukan penulis adalah melakukan berbagai aktifitas diantaranya melakukan persiapan diri, mencari dan mengumpulkan berbagai informasi, merumuskan masalah, menentukan fokus, mengolah informasi, menarik hipotesa dan inferensi terhadap realitas yang dihadapinya, berdiskusi, membaca, mengamati, dan lain sebagainya untuk memperkaya gagasan yang akan diproses selanjutnya. Pada tahapan kedua, penulis melakukan diskusi bersama untuk mengembangkan ide baru yang terdapat 
pada kerangka karangan dengan memanfaatkan informasi yang telah diperoleh sebelumnya. Tahapan ketiga adalah menulis. Setelah tahapan ini penulis melakukan penyempurnaan tulisan yang dihasilkan yang disebut sebagai tahap penyempurnaan. Kegiatan penyempurnaan dilakukan dengan penyuntingan dan perbaikan tulisan (revisi). Pembimbingan seperti ini dikemas oleh penulis dalam kegiatan PKM (Pengabdian Kepada Masyarakat) (Hastuti \& Setyawan, 2021).

Berkaca pada fakta bahwa kemampuan menulis siswa masih rendah, penulis mengadakan kegiatan yang dapat memberi manfaat untuk masyarakat yang disebut PKM yang memiliki kaitan dengan pengembangan literasi dalam bentuk pelatihan menulis cerita. Tujuan dari kegiatan ini adalah meningkatkan kemampuan menulis siswa sekolah dasar/sederajat. Dalam kegiatan pengabdian ini, siswa dilatih untuk melalui tahapan-tahapan menulis, sampai mereka berhasil menuliskan sendiri cerita mereka. Kegiatan pelatihan ini diharapkan dapat membantu menyukseskan Gerakan Literasi Sekolah (GLS).

\section{Metode Pelaksanaan}

Kegiatan pengabdian masyarakat ini diselenggarakan di MIS Darul Ulum Genengan yang beralamat di Desa Genengan, Kecamatan Doko, Kabupaten Blitar, Provinsi Jawa Timur. Sekolah ini dijadikan lokasi pengabdian dikarenakan kegiatan Gerakan Literasi Sekolah (GLS) belum berjalan optimal, terutama untuk kegiatan menulis. Peserta kegiatan pelatihan ini meliputi siswa kelas 4, 5, dan 6. Secara keseluruhan, peserta yang mengikuti pelatihan berjumlah 52 siswa. Kegiatan pelatihan ini diselenggarakan pada pada tanggal 7-13 September 2021.

Pelatihan menulis cerita ini menerapkan metode flipped classroom (kelas terbalik). Metode ini dipilih karena pembelajaran di sekolah masih menerapkan sistem tatap muka terbatas. Dalam satu minggu, siswa hanya masuk sebanyak 3 kali. Dengan demikian, integrasi pembelajaran daring dan tatap muka dalam bentuk flipped classroom dirasa menjadi metode yang tepat. Pada pelaksanaannya, siswa terlebih dahulu mempelajari materi secara daring. Materi tentang cerita dikemas dalam bentuk video yang diunggah ke laman YouTube, dan link dari video tersebut (https://youtu.be/_C23XZgynsY) dibagikan melalui grup WhatsApp. Setelah mempelajari materi di rumah, siswa dilatih untuk menulis cerita dan melatih kemampuan mendengar yang baik dari matri yang berikan dengan bimbingan guru (Setyawan et al., 2018).

Cerita yang dibuat oleh siswa bertema pengalaman pada masa pandemi. Mereka diberikan kebebasan untuk menulis pengalaman mereka, baik yang menyenangkan atau yang kurang menyenangkan, misalnya pengalaman belajar daring, bermain, berkarya, membantu orang tua, berkebun, memelihara binatang, dsb. Penilaian cerita siswa meliputi isi, organisasi, kosakata, tata bahasa, dan teknik penulisan (penggunaan tanda baca dan huruf kapital). Hasil penilaian tulisan siswa kemudian diinformasikan kepada siswa dan guru untuk dilakukan perbaikan.

\section{Hasil dan Pembahasan}

Terdapat dua fase dalam pelatihan menulis cerita ini, yaitu fase daring dan fase tatap muka. Pada fase daring, fokus kegiatan siswa adalah mempelajari konsep cerita melalui media video. Video dibuat dengan bantuan 
aplikasi Zoom dan PowerPoint, yang kemudian diunggah ke laman YouTube. Isi dari video meliputi konsep cerita, contoh-contoh cerita bertema pengalaman, dan instruksi menulis. Setelah menonton video, siswa diharapkan memiliki pemahaman awal tentang cerita, serta gambaran tentang cerita apa yang akan mereka tulis.

Pada fase tatap muka, kegiatan di kelas lebih banyak fokus pada latihan menulis. Namun, di awal pembelajaran, penulis kembali menerangkan secara singkat tentang konsep cerita serta contoh-contoh cerita seperti yang ditampilkan dalam video. Hal ini dilakukan karena tidak semua siswa bisa menonton video saat mereka di rumah. Siswa diberi kesempatan sebanyakbanyaknya untuk bertanya, atau berbagi pengalaman mereka. Setelah memberikan penjelasan kepada siswa, penulis meinginstruksikan siswa untuk mulai menulis. Kegiatan menulis di kelas ini terbagi menjadi dua tahap, yaitu tahap pra-penulisan dan tahap penulisan.

Pada tahap pra-penulisan, penulis membagikan tiga contoh cerita tentang pengalaman pada masa pandemi. Cerita-cerita tersebut dibuat sederhana agar siswa bisa menjadikannya sebagai contoh. Sebelum menulis, mereka terlebih dahulu harus memahami masing-masing cerita. Selesai membaca, penulis berdiskusi dengan siswa untuk membahas unsur-unsur instrinsik yang ada dalam cerita-cerita tersebut. Penulis bersama siswa menganalisis tema, tokoh, alur, dan latar dari masing-masing cerita. Hal ini bertujuan agar siswa memahami unsur-unsur yang nantinya akan mereka sertakan dalam cerita mereka. Gambar 1 menunjukkan proses membaca siswa pada tahap pra-penulisan.

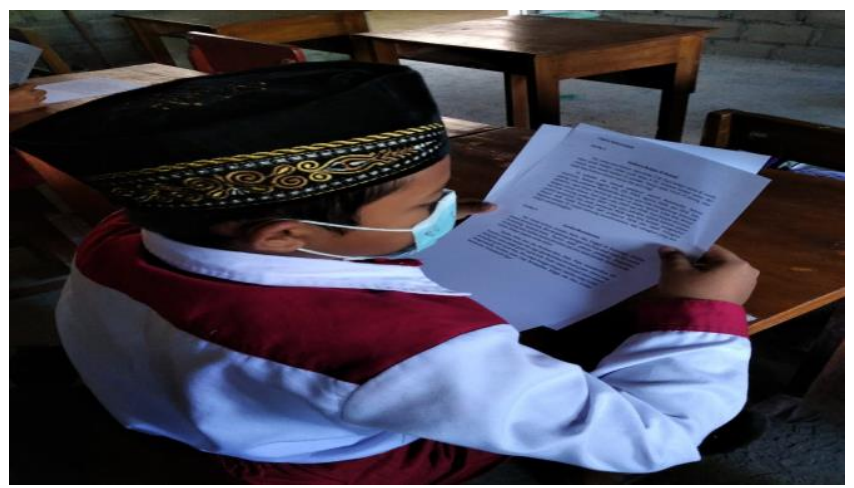

Gambar 1. Siswa membaca cerita pada tahap pra-penulisan

Setelah berdiskusi tentang unsur-unsur cerita, siswa mulai memasuki tahap penulisan. Mereka diberikan selembar kertas untuk menuangkan gagasan mereka. Pada latihan menulis ini, siswa dibimbing untuk menentukan tema cerita terlebih dahulu. Beberapa siswa yang kesulitan menentukan ide juga dibantu untuk mengingat kembali pengalamanpengalaman mereka yang berkesan. Setelah berhasil menentukan ide, siswa mulai menulis cerita mereka. Beberapa menit berjalan, beberapa siswa mengatakan bahwa mereka sudah selesai. Penulis berinisiatif untuk melihat tulisannya, dan memberikan saran untuk menambahkan sejumlah detail agar cerita mereka lebih menarik, seperti suasana yang mereka rasakan, objekobjek yang mereka lihat, atau apa yang mereka dengar ketika mereka mengalami kejadian yang mereka ceritakan. Hal ini bertujuan agar mereka memaksimalkan indera mereka dalam menuangkan gagasan, sehingga cerita 
yang mereka hasilkan bisa lebih hidup. Proses menulis ini berlangsung sekitar satu jam. Gambar 2 menunjukkan proses kegiatan menulis siswa.

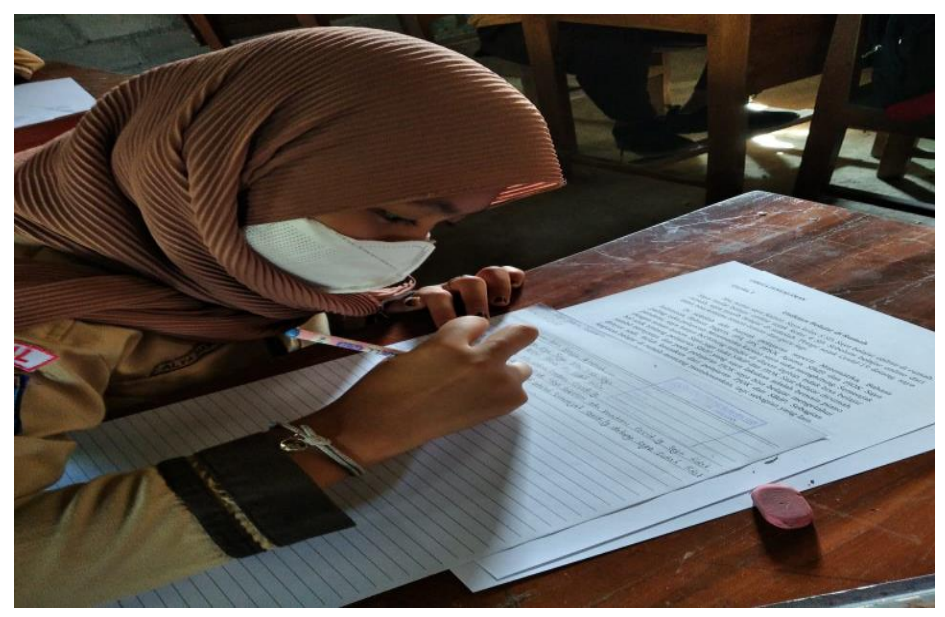

Gambar 2. Siswa menulis cerita

Pada saat kegiatan menulis berlangsung, penulis mendapati sejumlah siswa yang kesulitan dalam menulis. Mereka sebenarnya memiliki ide, namun terkendala pada teknik penulisan, misalnya penulisan ejaan yang tepat. Merespon hal ini, penulis bersama tim secara aktif membantu siswa-siswa yang mengalami kesulitan tersebut. Mereka dibimbing untuk menuliskan kata dengan benar, sesuai dengan apa yang ada di benak mereka. Selain itu, banyak siswa yang mengalami kesulitan dalam menentukan kosakata bahasa Indonesia. Hal ini terjadi karena dalam kesehariannya, mereka terbiasa menggunakan bahasa Jawa. Gambar 3 menunjukkan pendampingan yang dilakukan penulis dan tim pada siswa yang mengalami kesulitan menulis.

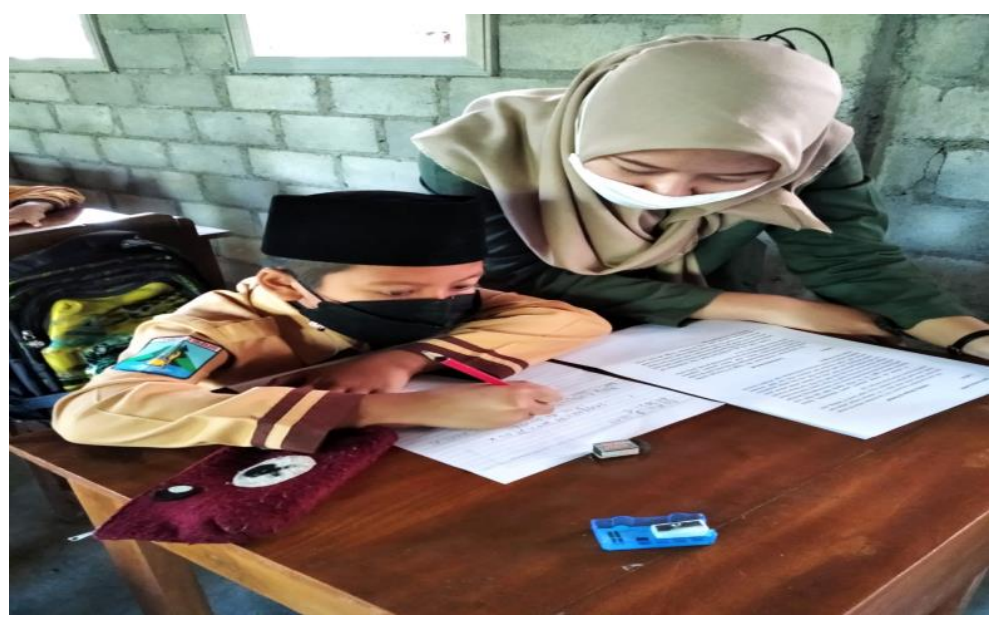

Gambar 3. Penulis dan tim membantu siswa yang mengalami kesulitan menulis

Setelah kegiatan menulis usai, siswa diberikan kesempatan untuk membacakan cerita mereka di depan kelas. Hal ini bertujuan untuk meningkatkan rasa percaya diri mereka dalam mengungkapkan ide. Sejumlah siswa terlihat gugup dalam membacakan ceritanya, namun banyak juga di antara mereka yang terlihat percaya diri. Tepuk tangan yang meriah diberikan kepada tiap siswa saat mereka selesai tampil. Gambar 4 menunjukkan kegiatan membaca cerita di depan kelas. 


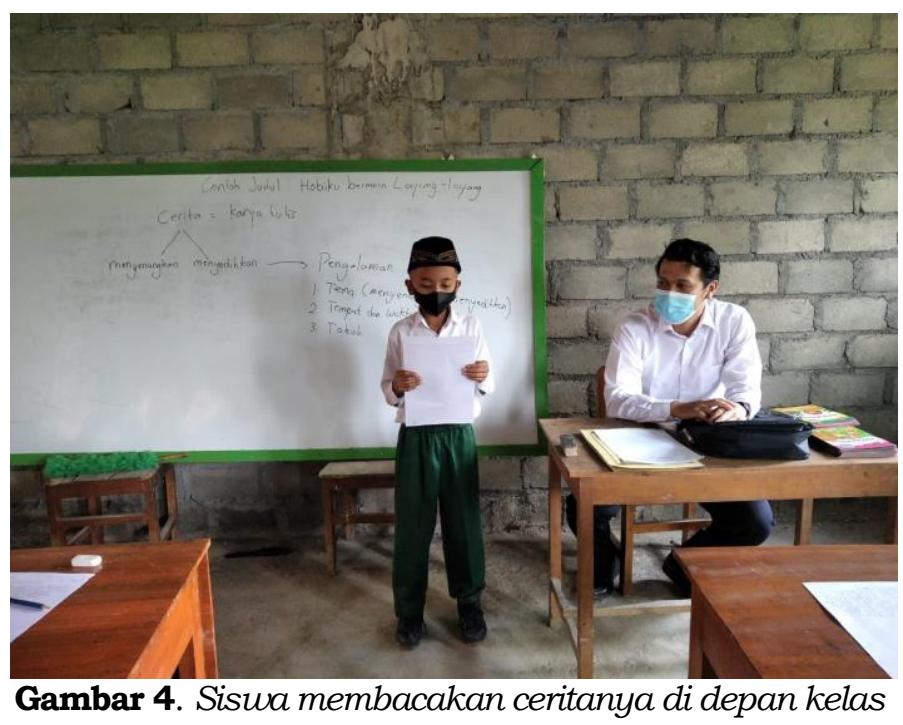

Setelah semua siswa tampil di kelas, penulis memberikan mereka hadiah atas kerja keras mereka dalam menulis cerita. Masing-masing siswa diberikan sebuah buku cerita agar kemampuan literasi mereka semakin meningkat, serta menginspirasi mereka untuk terus menulis. Mereka terlihat antusias saat menerima buku cerita, dan langsung membaca buku tersebut. Gambar 5 menunjukkan kegiatan membaca buku cerita sebagai penguatan dari kegiatan menulis yang baru saja mereka lakukan.

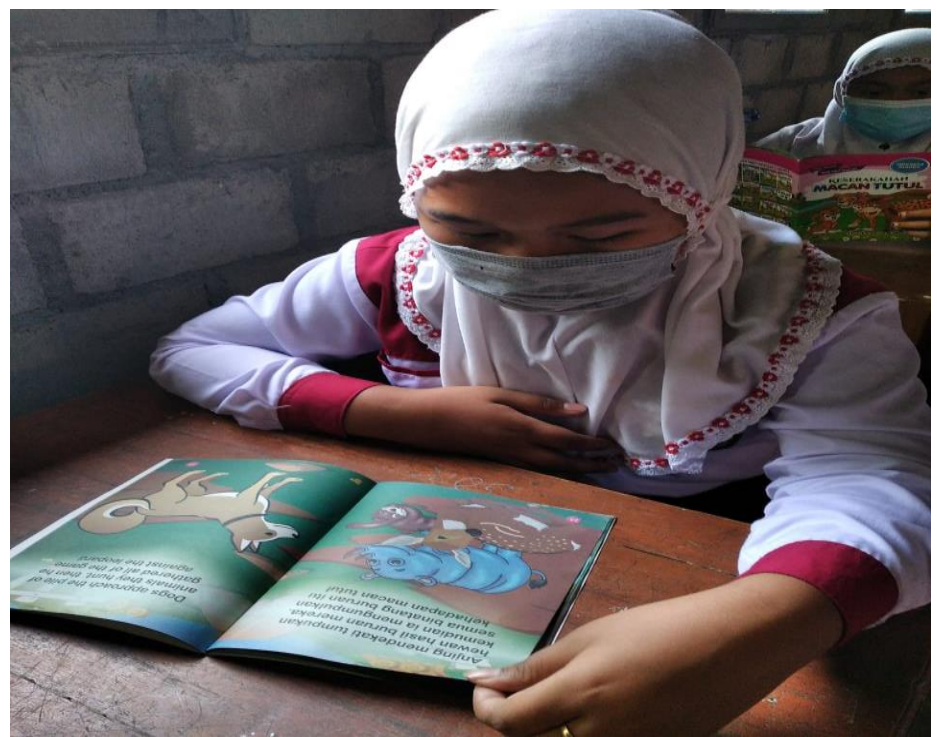

Gambar 5. Siswa membaca buku cerita sebagai penguatan literasi

Pada akhirnya, rangkaian kegiatan literasi yang dilakukan siswa berhasil menciptakan produk berupa cerita bertema pengalaman. Selain itu, mereka juga dibiasakan dengan kegiatan membaca agar kemampuan literasi mereka berkembang. Langkah selanjutnya, penulis dan tim mengevaluasi hasil karya siswa dan memberikan sejumlah umpan balik terkait dengan isi, organisasi, kosakata, tata bahasa, dan teknik penulisan. Selain itu, kami juga menentukan karya terbaik dari tiap kelas, untuk selanjutnya diberikan penghargaan berupa piagam dan hadiah. Pemberian penghargaan ini diharapkan mampu meningkatkan semangat mereka dalam menulis. Tabel 1 menunujukkan cerita termenarik dari tiap kelas. 
Tabel 1. Cerita Termenarik

\begin{tabular}{cccc}
\hline No. & Judul Cerita & Penulis & Kelas \\
\hline 1. & Belajar Berenang & M. Saiq, H. S. & IV \\
2. & Aku Suka Menggambar & Silvi Zahra M. & V \\
3. & Senangnya Menemukan & Yovi Aldiansyah & VI \\
& Layang-layang di Masjid & & \\
\hline
\end{tabular}

Cerita-cerita di atas terpilih berdasarkan sejumlah kriteria. Pertama, ide cerita yang disajikan menarik. Kemudian, alur cerita juga disusun dengan runtut, dan disajikan dalam beberapa paragraf. Kosakata dan tata bahasa yang digunakan oleh siswa juga cukup baik, sehingga cerita dapat terbaca dengan baik. Namun, pada aspek teknik penulisan masih perlu ditingkatkan, seperti penggunaan huruf kapital dan tanda baca. Hal ini juga dialami oleh sebagian besar siswa yang ikut serta dalam pelatihan menulis ini.

Berdasarkan pemaparan data di atas, terdapat beberapa hal yang layak untuk dibahas lebih lanjut. Pertama, kegiatan pengabdian ini mengadopsi metode flipped classroom. Metode ini cocok untuk diterapkan pada pembelajaran tatap muka terbatas pada masa pandemi. Pada saat siswa belajar daring, siswa memiliki banyak waktu untuk mempelajari konsep secara mendalam. Kemudian, pada saat siswa belajar secara tatap muka, mereka bisa mengaplikasikan konsep yang sudah mereka pahami di dalam kelas dengan bantuan guru. Pada kegiatan pelatihan menulis cerita ini, materi yang diberikan kepada siswa dikemas dalam bentuk video. Penggunaan video ini dimaksudkan untuk melibatkan siswa dalam pembelajaran, meningkatkan motivasi siswa, dan membuat pembelajaran menjadi lebih menarik (Goldstein, 2017; Clare, 2017). Video yang digunakan dalam pengabdian ini adalah video buatan penulis. Menurut Bergmann \& Sams (2014), video buatan guru lebih disarankan untuk pembelajaran daripada video yang sudah beredar di Internet. Hal ini dikarenakan video buatan sendiri dapat meningkatkan koneksi guru dan siswa. Tidak bisa dipungkiri, koneksi antara guru dan siswa merupakan elemen penting dalam pembelajaran. Terlebih selama pandemi, tidak adanya pembelajaran tatap muka membuat koneksi guru dan siswa menjadi terhambat, dan video buatan guru menjadi salah satu alternatif untuk menjaga koneksi tersebut.

Hal selanjutnya yang menarik dibahas adalah pendampingan belajar di dalam kelas. Dalam flipped classroom, pembelajaran aktif di kelas dapat dimaksimalkan karena materi sudah dijelaskan melalui video secara daring. Dengan demikian, waktu di kelas tidak banyak tersita untuk menjelaskan konsep. Pada pengabdian ini, pembelajaran aktif yang dimaksud adalah siswa diberikan banyak waktu untuk praktik menulis cerita. Pada saat siswa menulis cerita inilah penulis dan tim fokus untuk membantu siswa yang mengalami kesulitan. Kegiatan ini sejalan dengan temuan para ahli dan peneliti terdahulu bahwa flipped classroom memungkinkan guru dan siswa untuk melakukan pembelajaran aktif sekaligus memberi atensi khusus pada siswa yang mengalami kesulitan (Lo \& Hew, 2017; Reidsema et al., 2017; Bergmann \& Sams, 2014).

Saat kegiatan menulis berlangsung, siswa diajarkan untuk melalui tahapan-tahapan menulis. Sebelum praktik menulis, siswa diberikan beberapa bahan bacaan untuk membentuk pemahaman mereka tentang cerita bertema pengalaman. Siswa dibimbing untuk memahami unsur-unsur 
instrinsik cerita, sekaligus mempelajari teknik penulisan. Setelah membaca, siswa langsung praktik menulis cerita mereka masing-masing dengan bimbingan penulis. Seusai menulis, siswa diberikan umpan balik berupa komentar dan saran untuk memperbaiki tulisan. Tahapan-tahapan ini sesuai dengan teori yang disampaikan oleh Dalman (2016) bahwa kegiatan menulis setidaknya melalui tiga tahap, antara lain tahap pra-penulisan, penulisan, dan pasca penulisan.

Produk yang dihasilkan siswa dalam pengabdian ini adalah cerita tentang pengalaman pribadi, khususnya pada masa pandemi. Mereka dapat menciptakan tulisan tersebut dikarenakan mereka mengalami sendiri kegiatan yang mereka ceritakan, dan mereka menyukai kegiatan tersebut. Hal ini dapat dimaknai sebagai pembelajaran yang kontekstual dan terkait dengan keseharian dan pengalaman siswa. Hal ini merupakan salah satu teknik yang efektif dalam pembelajaran bahasa untuk anak-anak (Sari et al., 2020). Selain itu, berdasarkan hasil analisis cerita mereka, dapat disimpulkan bahwa tingkatan menulis siswa berada pada tingkat menengah. Pada tingkat ini, siswa mampu menciptakan karangan pendek (Iskandarwassid \& Sunendar, 2008). Hasil pengabdian ini menunjukkan bahwa kemampuan siswa dalam menulis sudah cukup baik. Walaupun mereka berpotensi mengalami learning loss akibat adanya pandemi, mereka tetap menunjukkan antusiasme tingggi dalam menulis dan mampu menghasilkan cerita yang bagus.

\section{Simpulan dan Tindak Lanjut}

Pengabdian masyarakat ini bertujuan untuk meningkatkan kemampuan menulis siswa sekolah dasar/sederajat. Dari rangkaian kegiatan yang dilakukan, siswa mampu menulis cerita mereka sendiri yang bertemakan pengalaman pribadi pada masa pandemi. Setelah dianalisis, cerita mereka memenuhi beberapa aspek, antara lain ide yang menarik, organisasi tulisan yang cukup bagus, dan kosakata serta tata bahasa yang cukup tepat. Namun, secara umum tulisan mereka masih perlu peningkatan pada aspek teknik penulisan. Banyak di antara siswa yang belum terampil dalam menggunakan huruf kapital dan tanda baca. Hal ini yang menjadi tindak lanjut dari pengabdian masyarakat ini. Penulis menyampaikan hasil tulisan siswa beserta analisisnya kepada para guru dan menyarankan mereka untuk lebih mengintensifkan kegiatan menulis di sekolah. Dengan cara ini, siswa yang sudah memiliki kemampuan baik dalam menulis akan semakin terasah bakatnya, sedangkan siswa yang masih mengalami kesulitan bisa semakin ditingkatkan kemampuannya. Selain itu, penulis juga berencana untuk mengadakan pelatihan menulis kembali, namun lebih fokus pada pelatihan menerapkan teknik penulisan yang baik. Kegiatan ini nantinya diharapkan dapat semakin meningkatkan kemampuan menulis siswa.

\section{Daftar Pustaka}

Bergman, J., \& Sams, A. (2014). The Flipped Classroom, CSE, 17(3), 24-27.

Clare, A. (2017). The Power of Video. In K. Donaghi, \& D. Xerri (Eds.), The Image in English Language Teaching (pp. 33-42). ELT Council.

Dalman, H. (2014). Keterampilan menulis. Jakarta: PT. Raja Grafindo Persada.

Goldstein, B. (2017). A history of video in ELT. The Image in English Language Teaching, 23-31. 
Guntur, T. H. (2008). Menulis Sebagai Suatu Keterampilan Berbahasa. Edisi Revisi. Angkasa: Bandung.

Hastuti, S. W. M., \& Setyawan, W. (2021). Community Service in Study Potential Technology of Education Tour and Business Prospects of Traders in Tulungagung. Mitra Mahajana: Jurnal Pengabdian Masyarakat, 2(2), 134-144. https://doi.org/https://doi.org/10.37478/mahajana.v2i2.952

Herry Setyawan, W., Budiman, A., Septa Wihara, D., Setyarini, T., Nurdyansyah, Rahim, R., \& Barid Nizarudin Wajdi, M. (2019). The effect of an android-based application on T-Mobile learning model to improve students' listening competence. Journal of Physics: Conference Series, 1175(1). https://doi.org/10.1088/1742-6596/1175/1/012217

Iskandarwassid \& Sunendar, D. (2008). Strategi pembelajaran bahasa. Bandung: PT Remaja Rosdakarya.

Kementerian Pendidikan dan Kebudayaan. (2017). Panduan Gerakan Literasi Nasional. Jakarta. Diakses dari https://gln.kemdikbud.go.id/glnsite/wpcontent/uploads/2017/08/pan duan-gln.pdf

Lo, C. K., \& Hew, K. F. (2017). A critical review of flipped classroom challenges in K-12 education: Possible solutions and recommendations for future research. Research and Practice in Technology Enhanced Learning, 12(1), 1-22. https://doi.org/https://doi.org/10.1186/s41039-016-0044-2

Permendikbud Nomor 21 Tahun 2015 Tentang Penumbuhan Budi Pekerti.

Diakses dari

https://jdih.kemdikbud.go.id/arsip/Permendikbud_Tahun2015_Nomor 21.pdf

Reidsema, C., Hadgraft, R., \& Kavanagh, L. (2017). Introduction to the flipped classroom. In The Flipped Classroom (pp. 3-14). Springer. https://doi.org/DOI 10.1007/978-981-10-3413-8_1

Sari, H. P., Fauzi, A., \& Primasari, Y. (2020). KREASI BAHAN AJAR BERKONSEP GAME UNTUK PEMBELAJARAN EKSTRAKURIKULER BAHASA INGGRIS TINGKAT SEKOLAH DASAR. JABN, 1(2), 51-63.

Sari, H. P., \& Setiawan, W. H. (2021). Peningkatan Teknologi Pendidik Pesantren Anak Sholeh melalui MEMRiSE: Coaching \& Training. Prima Abdika: Jurnal Pengabdian Masyarakat, 1(3), 81-90.

Setyawan, W., Rusijono, M., \& Jannah, M. (2018). T-Mobile Learning Android Model-Based to Improve Students' Listening Capability. 1st International Conference on Education Innovation (ICEI 2017). https://doi.org/10.2991/icei-17.2018.96

Undang-undang Republik Indonesia nomor 20 tahun 2003 tentang sistem pendidikan nasional. (2003). Jakarta: Pemerintah Republik Indonesia. http:// pendis.kemenag.go.id/file/dokumen/uuno20th2003ttgsisdiknas.p df 